\title{
Cystic Change
}

National Cancer Institute

\section{Source}

National Cancer Institute. Cystic Change. NCI Thesaurus. Code C41454.

A microscopic finding indicating the formation of cystic structures in a tissue sample. 